\title{
Katarzyna Kuczyńska-Koschany
}

Uniwersytet im. Adama Mickiewicza w Poznaniu

\section{Majdan, agora i grób (notatki na marginesie tomu Zwrotnik Ukraina)}

„Czasami rzeczywistości jest zbyt wiele”.

Serhij Żadan

W końcu października 2013 roku byłam przez tydzień w Czerniowcach, stolicy Bukowiny, na przepięknym pograniczu ukraińsko-rumuńsko-mołdawskim. Tylko architektura przedmieść-blokowisk przypominała tu o czasach Związku Radzieckiego. Mieszkańcy Czerniowec mówili wszystkimi językami, w jakich ich zagadnięto. Właśnie z Drohobycza i reszty świata przyjechali wielbiciele autora Sklepów cynamonowych (które Jurij Andruchowycz przetłumaczył właśnie kongenialnie na ukraiński) i wszyscy uczestniczyliśmy w Dniach Schulza w Czerniowcach. Do późnej nocy siedzieliśmy w pięknych, pamiętających czasy monarchii naddunajskiej, kafejkach (bądź na tamte czasy świadomie stylizowanych), zachwyceni ciepłą jesienią spacerowaliśmy godzinami po tym niebywałym mieście, o którym Andruchowycz w Leksykonie miast intymnych napisał:

Ulubieniec chasydów i Hucułów, Franciszek Józef (nie wiadomo, czy ten sam), w swoich łańcuchowych wizjach widział Czerniowce jako wschodnią metropolię, znacznie większą od Lwowa i Wiednia, z przynajmniej kilkoma wysokimi budynkami i znacznie głębszym cmentarzem. Kiedy zaś ujrzał z powietrza Nowy Jork, to on także nie wydawał mu się większy niż Czerniowce. Zresztą tak naprawdę żadne $\mathrm{z}$ tych miast nie istnieje. Nowy Jork nie istnieje, bo samo jego istnienie świadczyłoby o materialnym uchybieniu, którego dopuścił się Bóg. Czerniowce nie istnieją, bo cóż mógłby wówczas wymyślać ten twórca? (Andruchowycz 2014a, 80) 
25 maja 2014 roku, w dniu ukraińskich wyborów prezydenckich, znalazłam się w Drohobyczu i Truskawcu, z okazji kolejnej edycji festiwalu Schulzowskiego. Był środek wiosny, zieleń, słońce, atmosfera święta. Wszystko kwitło. I tylko w każdym kościele, cerkwi, na uniwersytecie, w hotelu, w muzeum, w każdym miejscu publicznym stały fotografie z czarnymi wstążkami. Święto mieszało się z żałobą. Na zachodniej Ukrainie wszyscy wiedzieli, że na wschodniej giną ludzie, ale widzieli to w telewizji. To tak, jakby w Poznaniu oglądać wojnę toczącą się w Lublinie - wszyscy mieli, wszyscy mieliśmy dojmujące poczucie nierzeczywistości. Nawet proza Schulza wydawała się zdumionej wyobraźni - istniało tam coś w rodzaju wyobraźni zbiorowej, ponadnarodowej i ponadpokoleniowej - bliższa rzeczywistości.

Co stało się pomiędzy późną jesienią 2013 a późną wiosną 2014? Pomiędzy była Niebiańska Sotnia, pomiędzy była bezprawna aneksja Krymu i agresja przeprowadzona pod pozorem pomocy humanitarnej, tchórzliwa ucieczka Wiktora Janukowycza do Rosji, ale przede wszystkim - był Majdan.

Czym był Majdan, zaświadcza tom szkiców, głosów, zapisków pt. Zwrotnik Ukraina pod redakcją Jurija Andruchowycza, wydany przez wydawnictwo Czarne w 2014 roku. Zaświadcza o tym, jak w bólach i krwawo rodzi się na Ukrainie społeczeństwo obywatelskie, zaświadcza wielogłosowo: głosami samych Ukraińców, żyjących w kraju i na emigracji, Niemców (tu znakomity Martin Pollack), Polaków i Rosjan (dysydentów, przyjaciół Moskali), wreszcie głosami historyków i znawców spoza Europy Środkowej, tak przenikliwych jak Timothy Snyder. Autor Skrwawionych ziem stawia diagnozę, iż to, co zdarzyło się na Ukrainie, było „klasyczną rewolucją ludową” (Andruchowycz 2014b, 154), próbą wyzwolenia od urzędującego prezydenta Janukowycza, „pospolitego przestępcy gwałciciela i złodzieja”, jak to określa amerykański historyk, „na ogromną, chyba wręcz bezprecedensową skalę” i próbą odmiany kraju rządzonego przez oligarchię (,większość bogactw kraju znalazła się w rękach ludzi, która zmieściłaby się w windzie”) (Andruchowycz 2014b, 154). Kiedy groteskowy dyktator Janukowycz ma już krew na rękach i postanawia zostać raczej marionetką Władimira Putina niż kimś, kto podpisuje umowę stowarzyszeniową z Unią Europejską, dzieje się rzecz nadzwyczajna:

Tu na scenę wkracza samotny, odważny ukraiński buntownik, znany dziennikarz śledczy. Śniadoskóry, namierzony przez reżim ze względów rasowych. A do tego muzułmanin i Afgańczyk. Jednym słowem, Mustafa Najem, człowiek, który rozpętał rewolucję. Za pomocą mediów społecznościowych zwołał studentów 
i młodzież na główny plac Kijowa, żeby wyrazili poparcie dla opcji europejskiej.

Plac to po ukraińsku majdan, co zresztą jest arabskim słowem. W pierwszych dniach protestu studenci nazwali ten plac Euromajdanem (Andruchowycz 2014b, 156-157).

Czym była i jaka była obywatelska rewolucja na kijowskim Majdanie, a potem także na innych majdanach, które cudownie rozmnożyły się w całej Ukrainie, daje pojęcie Snyder, odczytując listę poległych wtedy, gdy zabijano już jawnie: pierwszy zginął Ormianin, potem - Białorusin, potem zginęli Ukraińcy ukraińsko- i rosyjskojęzyczni, Rosjanie, Polacy, Żydzi. Timothy Snyder, pozbawiony wyższości człowieka Zachodu, uważny czytelnik ukraińskiej rewolucji - nie aksamitnej, bo spacyfikowanej, ale też nie ufundowanej na przemocy, lecz pokojowej i otwartej, proeuropejskiej („To była ludowa rewolucja, z całym właściwym takim wydarzeniom bałaganem, zamieszaniem i opozycją") (Andruchowycz 2014b, 163) zauważa:

Czy zdarzyło się kiedykolwiek, żeby ludzie związani z kulturami ukraińską, rosyjską, białoruską, ormiańską, polską i żydowską ginęli w rewolucji wywołanej przez muzułmanina? Czy my, tak dumni ze swojej różnorodności i tolerancji, możemy sobie przypomnieć choć trochę podobne wydarzenia w dziejach naszych krajów? Ludzie zwyciężyli dzięki zwyczajnej fizycznej odwadze. Ministrowie spraw zagranicznych państw europejskich, którzy mieli obejrzeć krwawy spektakl, zobaczyli coś innego - skuteczną obronę Majdanu (Andruchowycz 2014b, 159-160).

Snyder pisał tekst w marcu 2014 roku, już po zajęciu przez Rosję Krymu, co nazywa „niesprowokowanym atakiem jednego państwa na suwerenne terytorium drugiego" (Andruchowycz 2014b, 163). Wojna rosyjsko-ukraińska nie jest jednak tematem tomu Zwrotnik Ukraina. Tematem jest obywatelska przemiana, znakomita mobilizacja społeczeństwa nie do głębi zsowietyzowanego, tęskniącego za wolnością, godnie odpowiadającego na próbę zniewolenia.

Spojrzenie Snydera, jako spojrzenie z zewnątrz, jest w tym inteligentnie skomponowanym tomie umiejętnie równoważone punktami widzenia samych uczestników i współtwórców Majdanu. Ci podejmują zarówno próby oddania aury Majdanu, jak też próby zdefiniowania jego istoty. I tak Katia Petrowska, rocznik 1970, kijowianka i stała felietonistka „Frankfurter Allgemeine Sonntagszeitung”, pisze, że „Majdan stał się podmiotem politycznym, uosabia rewolucje, powstania i karnawały z wielu epok równocześnie” (Andruchowycz 2014b, 53), a chwilę później dodaje: 
Rzadko przeżywa się coś takiego, może zaledwie raz w życiu, że ludzie zmieniają się radykalnie, wyciągają ze swojego wnętrza coś, czego się po nich nikt nie spodziewał, jak gdyby z małego mieszkanka w bloku przenieść się do niekończącej się amfilady pokoi. Tak właśnie było teraz, wydawało się, że ludzie zostali zmuszeni do podejmowania najtrudniejszych decyzji i odkrywali przy tym nieoczekiwane przestrzenie duchowości (Andruchowycz 2014b, 53-54).

Tekst Petrowskiej nosi tytuł Mój Kijów i pokazuje rodzaj nieoczekiwanego przebudzenia, przypominającego polskie lata KOR-u, „Solidarności”, dni Kongresu Kultury Polskiej, przerwane przez stan wojenny w 1981 roku. Kluczowe jest tu słowo „godność”:

Przyjaciółka z Moskwy umieściła wideo z nagraniem ostatniego wykładu naszego dawno nieżyjącego profesora Jurija Łotmana z Tartu. Zaczął od tego, że śmierć nie jest czymś najgorszym. Przeraziłam się. Najgorsze jest poniżenie, plucie w twarz. Przeraziła mnie paląca aktualność jego słów, bo wtedy, przed ponad dwudziestu laty, mówił o etyce pojedynku, o honorze i jego naruszeniu, o wojnie i pokoju, o księciu Bołkońskim, który nie kłania się przed salwą artyleryjską i dlatego ginie. Pozostaje niewyjaśnioną zagadką historii, dlaczego człowiek, który przez lata znosi poniżenie, nagle przestaje to robić i zaczyna się bronić, zdecydowanie i nieustępliwie. Zagadką jest również, dlaczego masy ludzi na Ukrainie jakby odruchowo opowiedziały się za honorem i sprawiedliwością, podczas gdy w mojej ukochanej Rosji większość ludzi, wspólnota narodowa, idzie za hasłami zwycięstwa i wyśpiewuje poparcie dla władzy. Nie spodziewałam się, że tak daleko zajdziemy, ale to, co teraz rozgrywa się w moim kraju, odkrycie własnej godności, było cudem, a ja czuję jego gorycz, bo kto raz odkryje tę godność, tego czeka wiele goryczy (Andruchowycz 2014b, 57-58, podkreślenia moje Katarzyna Kuczyńska-Koschany).

Jurko Prochaśko, germanista i psychoterapeuta ze Lwowa, rocznik 1970, nazywa Majdan zaczątkiem „Małej Europejskiej Rewolucji”, upomina się nie tylko o Szwejka, ale też o Rolanda dla Europy Środkowej. Serhij Żadan, wybitny ukraiński pisarz, rocznik 1974, pisze jak Majdan sprawił, że nareszcie Ukraińcy sami o sobie zaczęli myśleć: „obywatele”.

Najprzenikliwszą definicję Majdanu znalazłam jednak w eseju (i po trosze reportażu), urodzonej w Orwellowskim 1984 roku, niezależnej wydawczyni, Kateryny Miszczenko, pt. Czarny punkt. Jej formuła stała się tytułem mojego omówienia, bo najlepiej - jak mi się zdaje - streszcza to, co działo na Ukrainie począwszy od grudnia 2013 roku: 


\begin{abstract}
Majdan to agora i grób. Miejsce, gdzie Ukraińcy narodzili się na nowo jako podmiot polityczny, i miejsce największej tragedii w naszej dwudziestoletniej historii. W dwoistości Majdanu przejawia się moja, i prawdopodobnie nie tylko moja, codzienność. W niej widzę nieodległą przeszłość i planuję przyszłość. Majdan to także jedyne miejsce, gdzie chcę przemawiać, jeśli mam być uczciwa wobec samej siebie. (Andruchowycz 2014b, 24)
\end{abstract}

Wybrałam ten tom, by go omówić, a raczej on mnie wybrał. Czytany z rosnącym zdumieniem, potwierdzał jednak moje naoczne obserwacje ukraińskie, suplementował rozmowy tam toczone, werbalizował moje niewysłowione intuicje. Myślę, że jest przeciwwagą polskiego dyskursu medialnego, silnie skoncentrowanego na agresji Putinowskiej Rosji; tymczasem warto - przede wszystkim - dostrzec (i pomóc dostrzegać innym, młodszym, to zadanie dla nauczycieli humanistów wobec ich uczniów - gimnazjalistów i licealistów), że metamorfoza Ukrainy zaczęła się na Ukrainie. Sami zawsze jesteśmy zirytowani, gdy słyszymy, że żelazna kurtyna zaczęła się rwać dopiero przy murze berlińskim, a nie już przy Okrągłym Stole.

Odmiana Ukrainy zaczęła się na Ukrainie, dzięki obywatelom-Ukraińcom, i tam się wciąż dokonuje. Powinniśmy tu, w Polsce, tej przemianie, odważnie i tak długo, jak będzie trzeba, asystować.

\title{
Bibliografia
}

Andruchowycz Jurij, 2014a, Leksykon miast intymnych. Swobodny podręcznik do geopoetyki i kosmopolityki, przeł. Kotyńska K., Wydawnictwo Czarne, Wołowiec 2014.

Andruchowycz Jurij (red.), 2014b, Zwrotnik Ukraina, przeł. Jankowska H., Jarosz P.,

Kotyńska K., Niedenthal K., Petryk M., Rosenau A., Sowińska A., Wydawnictwo Czarne, Wołowiec 2014.

Katarzyna Kuczyńska-Koschany - prof. UAM dr hab., polonistka, komparatystka, eseistka, prozaik. Zajmuje ją przede wszystkim: poezja i jej interpretacja, kultura Żydów polskich i niemieckich, Zagłada Żydów w Europie, relacje intersemiotyczne w poezji i plastyce. Autorka m.in. takich książek jak Rilke poetów polskich (2004), Rycerz i Śmierć. O „Elegiach duinejskich” Rainera Marii Rilkego (2010), Interlinie w ciemności. Jednak interpretacja (2012), ,Wsje poety Żydy”. Antytotalitarne gesty poetyckie i kreacyjne wobec Zagłady oraz innych doświadczeń granicznych (2013). Współpracuje z „Zeszytami Literackimi”, publikowała także w „Polonistyce”. 